\title{
O związkach literatury i filozofii na przykładzie postaci Iwana Karamazowa
}

\author{
Marcin Kochanowski
}

https://orcid.org/0000-0003-2640-2748

Stanisław Gałkowski w artykule Granica filozofii. Metafora w filozofii na przykładzie języka Józefa Tischnera wskazuje na konieczność rozgraniczenia pomiędzy literaturą a filozofią, jako dziedziną, której wymogiem jest intersubiektywna komunikowalność i sprawdzalność tez w jej ramach głoszonych. Opierając się na przykładzie postaci Iwana Karamazowa i jego egzystencjalnych dylematach, które stanowiły podłoże filozoficznej refleksji Lwa Szestowa i Mikołaja Bierdiajewa wskazuję, że filozofia mieści w sobie zarówno obszary badawcze, takie jak logika, które nie mają punktów stycznych z literaturą, jak i takie dziedziny, jak filozofia egzystencji bądź metafizyka, które korzystały i nadal korzystają z dorobku literackiego, zarówno pośrednio jako źródła inspiracji jak i bezpośrednio - jako tekstów stricte filozoficznych, będących podstawą polemik i dalszych badań, przy czym nie stanowi to zagrożenia dla autonomii filozofii wobec literatury.

Słowa kluczowe: literatura, filozofia, rozgraniczenie, niejednoznaczność, Dostojewski, Szestow, Bierdiajew

MARCIN KOCHANOWSKI, doktorant w Instytucie Filozofii, Socjologii i Dziennikarstwa Wydziału Nauk Społecznych Uniwersytetu Gdańskiego; adres do korespondencji: Uniwersytet Gdański, Wydział Nauk Społecznych, Instytut Filozofii, Socjologii i Dziennikarstwa, ul. Bażyńskiego 4, 80-309 Gdańsk; e-mail: piglet14@wp.pl 
W artykule Granica filozofii. Metafora w filozofii na przykładzie języka Józefa Tischnera ${ }^{1}$ który ukazał się w antologii Filozofia $w$ literaturze, literatura $w$ filozofii, Stanisław Gałkowski - w związku z problematyką metafory w filozofii Józefa Tischnera - formułuje tezę o konieczności rozgraniczenia pomiędzy literaturą a filozofią, traktowaną jako dziedzina, której wymogiem jest intersubiektywna komunikowalność i sprawdzalność jej tez. Zdaniem autora, zastosowanie metafory, a zatem narzędzia literackiego, stanowi zagrożenie dla racjonalności dyskusji filozoficznych, niemożliwa jest bowiem racjonalna dyskusja, gdy przynajmniej jedna ze stron posługuje się metaforą. W tej sytuacji bowiem dyskusja nie polega na zestawieniu dwóch racjonalnych sądów o rzeczywistości, lecz dwóch interpretacji metafory ${ }^{2}$. Podwójne zapośredniczenie w tym, co subiektywne (czyli w tym jak metaforę „wyczuwa” jej twórca, oraz w równie subiektywnej interpretacji jej odbiorcy), powoduje, że traci rację bytu pytanie o to, co dokładnie było intencją autora - podobnie jak się to ma w przypadku odbioru sztuki ${ }^{3}$.

Jakkolwiek zasadniczy rdzeń wywodów autora dotyczy przede wszystkim konieczności dostrzeżenia różnic w języku używanym w literaturze i filozofii, to zauważyć należy, że problem potencjalnego rozgraniczenia filozofii i literatury na podstawie uznania jednoznaczności wypowiedzi jako atrybutu filozofii i przeciwstawienia temu niejednoznaczności przekazu literackiego, którego odbiór jest czysto subiektywny, wykracza poza samą kwestię czystej formy językowej wypowiedzi, w tym stosowanych w jej ramach środków formalnych.

Zagadnienie naukowego charakteru filozofii i postulat jej ograniczenia poprzez eliminację z jej pola badawczego wszelkich kwestii, najogólniej rzecz ujmując, metafizycznych, a zatem takich, o których nie sposób sformułować sądów nadających się do jednoznacznego zweryfikowania, podnoszone było już przez filozofów analitycznych, w szczególności działających w Kole Wiedeńskim. Dyskusja zainicjowana w ten sposób dotyczyła jednakże raczej stosunku filozofii do innych nauk oraz ustalenia, czy i pod jakimi warunkami sama filozofia może być uznana

\footnotetext{
${ }^{1}$ Stanisław Gałkowski, „Granica filozofii. Metafora w filozofii na przykładzie języka Józefa Tischnera”, w: Filozofia w literaturze, literatura w filozofii, red. Agnieszka Iskra-Paczkowska, Stanisław Gałkowski i Marek Stanisz (Rzeszów: Wydawnictwo Uniwersytetu Rzeszowskiego, 2013), 42-51.

${ }^{2}$ Tamże, 48.

${ }^{3}$ Tamże, 49.
} 
za naukę. Tymczasem autor przywołanego artykułu, odwołując się do postulatów filozofów analitycznych, w tym sensie i podobnie jak oni uznając filozofię za naukę sensu stricto, a zatem działalność której wyniki mają charakter intersubiektywnie komunikowalny i weryfikowalny, akcentuje konieczność wytyczenia granicy nie pomiędzy filozofią i innymi naukami, lecz pomiędzy filozofią i literaturą. Otóż zauważyć należy, że stanowisko takie może budzić pewne wątpliwości wobec faktu, że dzieła literatury w przeszłości pełniły rolę nie tylko źródła inspiracji dla filozofii, ale też niejednokrotnie same w sobie stanowiły źródło filozoficznej refleksji. Niekiedy wypowiedzi niewątpliwie o charakterze ściśle filozoficznym przybierały formę literacką - jak np. w przypadku Tako rzecze Zaratustra Fryderyka Nietschego. Nota bene był filozofem, który metaforą posługiwał się nader często i chętnie. Jeśli chodzi o rolę samej metafory jako takiej w filozofii, to dość chyba wspomnieć jaskinię Platona. Owa refleksja filozoficzna zatem częstokroć daleka była od jednoznaczności w rozumieniu nadawanym temu określeniu przez filozofię analityczną - a wręcz przeciwnie, jej cechą zasadniczą było formułowanie nierozstrzygalnych dylematów i antynomii, brak konkluzywnych rozstrzygnięć, poruszanie się w sferze niejednoznaczności i pytań pozbawionych odpowiedzi. Jako przykład tego wskazać można pisarstwo Fiodora Dostojewskiego.

2.

Próba zrekonstruowania wszystkich problemów natury filozoficznej, pojawiającej się w dziełach rosyjskiego pisarza, jak również przedstawienie związków łączących jego pisarstwo z tradycją filozoficzną rozmaitych nurtów, z oczywistych względów dalece przekraczałoby ramy niniejszego artykułu, jednakże dla celów, jakie postawił sobie jego autor, wystarczy przeanalizowanie filozoficznej oceny postaci Iwana Karamazowa sformułowanej przez dwóch rosyjskich filozofów działających w podobnym czasie, dla których twórczość Dostojewskiego stanowiła istotny punkt odniesienia - a mianowicie Mikołaja Bierdiajewa i Lwa Szestowa.

Przed podjęciem dalszych rozważań warto zauważyć, że sam Dostojewski łączył w sobie odległe zdawałoby się elementy światopoglądu i przekonań. W okresie przynależności do kółka Pietraszewców entuzjasta utopijnego socjalizmu 
w wydaniu Fourierowskim ${ }^{4}$, następnie jego gwałtowny krytyk ${ }^{5}$ oraz autor Biesów, w których ukazał grupę nihilistycznych rewolucjonistów, zamierzających aktami terroru zaprowadzić bezwzględną tyranię, deklarujący swą „niewiarę i zwątpienie”, a równocześnie wierzący, że „nie ma nic piękniejszego, głębszego, milszego, rozumniejszego, odważniejszego i doskonalszego niż Chrystus"7. Tą samą rozpiętość widać także w jego utworach - z jednej strony postać Raskolnikowa, stanowiąca upostaciowanie nihilistycznych idei Jedynego Maxa Stirnera, ogłaszającego: „Moją sprawą nie jest ani sprawa Boga, ani sprawa Człowieka, nie jest nią Prawda, Dobro, Prawo czy Wolność - Moja sprawa to tylko to, co moje"8 oraz nadczłowieka Nietzschego, uzurpujących sobie prawo do odrzucenia praw i kodeksów moralnych w imię dążenia do jednostkowej i indywidualnej wielkości, co w konsekwencji prowadzi do zbrodni (notabene Nietzsche w swym Zmierzchu bożyszcz oraz w korespondencji z krytykiem Georgiem Brandesem wypowiadał się o Dostojewskim z dużym uznaniem ${ }^{9}$ ), z drugiej zaś - bohater Notatek z podziemia, który w imię obrony swej niepowtarzalnej, jednostkowej i indywidualnej egzystencji odrzuca nie tylko przynależność do społeczeństwa i wszystkie jego prawa, ale także marzenia o utopii upostaciowanej przez Kryształowy Pałac. Charakterystyczne jest, że utwór ten spotkał się z oskarżeniami o nihilizm, na co wpływ miała ingerencja cenzorska, w wyniku której z powieści usunięto zakończenie w którym bohater nawraca się.

Zdaniem Ryszarda Przybylskiego, owa interwencja cenzury wypaczyła sens utworu, w którym pierwsza część zawierająca krytykę socjalistyczno-utylitarnej utopii miała przedstawiać zaledwie pierwszy etap w rozwoju duchowym bohatera $^{10}$, jednakże Michał Kruszelnicki zauważa, iż Dostojewski miał okazję przywrócić wycięty przez cenzurę fragment - czego jednak nie uczynił, mimo tego, że

${ }^{4}$ Leonid Grossman, Dostojewski, tłum. Seweryn Pollak (Warszawa: Czytelnik, 1968), 99.

${ }^{5}$ Tamże, 276.

${ }^{6}$ Tamże, 163-164.

${ }^{7}$ Ryszard Przybylski, Dostojewski i „przeklęte problemy”(Warszawa: Wydawnictwo Sic!, 2010), 165.

${ }^{8}$ Max Stirner, Jedyny i jego własność, tłum. Joanna i Adam Gajlewiczowie (Warszawa: Wydawnictwo Naukowe PWN, 1995), 6.

${ }^{9}$ Borys Bursow, Osobowość Dostojewskiego, tłum. Alicja Wołodźko (Warszawa: Państwowy Instytut Wydawniczy, 1983), 309.

${ }^{10}$ Przybylski, Dostojewski i „przeklęte problemy”, 151. 
skarżył się na ingerencję cenzury ${ }^{11}$. Także poszczególne utwory Dostojewskiego cechuje ustawiczny konflikt racji, ścieranie się postaw, niejednoznaczność. W kontekście tego Michaił Bachtin pisze o „mnogości samodzielnych głosów i świadomości, prawdziwej polifonii równorzędnych głosów”. Bohaterów prozy Dostojewskiego nazywa Bachtin „podmiotami własnego słowa, posiadającego bezpośrednią ważkość znaczeniową"12. Przy tej okazji Michał Kruszelnicki czyni interesującą uwagę, że występujący na kartach powieści rosyjskiego pisarza przestępcy i buntownicy robią o wiele bardziej interesujące wrażenie niż postacie pozytywne $^{13}$. Wyjaśniając ową niejednoznaczność postaci Dostojewskiego, Cezary Wodziński wskazuje z kolei na specyfikę „,rosyjskiej duszy”, wyrażającej się transgresją dobra i zła, poszukiwaniem przestrzeni poza granicami tego świata, dążeniem do łaski, która „przydarza się warunkowo i sama dyktuje warunki swego wydarzania się" ${ }^{14}$. Jedną $\mathrm{z}$ takich postaci niejednoznacznych i tragicznych zarazem jest Iwan Karamazow.

Wspomniana przez Michaiła Bachtina cecha bohaterów prozy Dostojewskiego, owo bycie "podmiotami własnego słowa”, uczynienie z nich przez autora nośnikami wykształconych w pełni poglądów i samodzielnych postaw, przemawianie własnym, świadomym, indywidualnym i niezależnym głosem pośród innych postaci zajmujących podobne, samodzielne miejsce sprawia, że możliwe staje się przeprowadzenie zabiegu interpretacji tych postaci nie tylko na polu czysto literackim lecz, poprzez potraktowanie ich jako w pewnym sensie odrębnych i samodzielnych bytów wyrażających określoną postawę filozoficzną - dokonanie interpretacji i oceny ich postaw na gruncie filozoficznym właśnie. Egzegeza tychże postaw i poglądów w aspekcie filozoficznym dokonywana była co najmniej kilkukrotnie - by wspomnieć tu Alberta Camusa i Karla Jaspersa, a także dwójkę rosyjskich filozofów, o których była już mowa - czyli Lwa Szestowa i Mikołaja Bierdiajewa.

\footnotetext{
${ }^{11}$ Michał Kruszelnicki, Dostojewski. Konflikt i niespełnienie(Warszawa: Wydawnictwo Naukowe Scholar, 2017), 50.

${ }^{12}$ Michaił Bachtin, Problemy poetyki Dostojewskiego, tłum. Natalia Modzelewska (Warszawa: Państwowy Instytut Wydawniczy, 1970), 11.

${ }^{13}$ Kruszelnicki, Dostojewski, 246.

${ }^{14}$ Cezary Wodziński, Trans, Dostojewski, Rosja (Gdańsk: Fundacja Terytoria Książki, 2018), 96.
} 
Dla Mikołaja Bierdiajewa Iwan Karamazow to przede wszystkim buntownik, który opacznie pojmując wolność, w jej imieniu buntuje się przeciw Bogu. Zostaje on postawiony w jednym rzędzie z Raskolnikowem i Stawroginem, będącymi „wędrowcami po drogach samowolnej wolności”, przy czym Iwan Karamazow stanowi „ostatni etap dróg wolności, która przekształciła się w samowolę i bunt przeciwko Bogu"15. Tak pojmowana wolność ostatecznie zwraca się przeciw sobie, przekształcając się w samowolę i, co charakterystyczne, usytuowaną z nią przez Bierdiajewa w jednym rzędzie autoafirmację człowieka. Konsekwencją jest negacja nie tylko Boga, ale także świata, człowieka i samej wolności ${ }^{16}$. W ujęciu tym Iwan Karamazow jest zatem nihilistą, którego idea wolności prowadzi poprzez odrzucenie kolejnych wartości do idei całkowitego zniewolenia, symbolizowanej przez Wielkiego Inkwizytora; jest też ateistą, który wybiera wolność, która nie jest darem Boga, lecz „wolność bezbożną” ${ }^{17}$, prowadzącą w efekcie do przemocy. Pisząc o przyczynach buntu Karamazowa przeciw Bogu, Bierdiajew przypisuje podobny bunt rewolucjonistom rosyjskim, wskazując, że łza dziecka, przeciwko której buntował się Karamazow, jest elementem indywidualnego losu nacechowanego wyższym sensem i będącego składnikiem Boskiego porządku świata. Zdaniem rosyjskiego filozofa, sprzeciw wobec owej łzy stanowi ateistyczny bunt przeciwko Bogu, w imię szczęśliwego i pełnego rozkoszy życia na ziemi ${ }^{18}$.

W zupełnie inny sposób przedstawia się postać Iwana Karamazowa w myśli Lwa Szestowa. Zauważyć należy na wstępie pewną niekonsekwencję w ocenie tej postaci. W Na szalach Hioba Szestow uznaje Karamazowa za „człowieka wykształconego”, pozostającego „po stronie Claude’a Bernarda”, a zatem za kogoś, kto odrzuca Boga, opowiadając się za nauką, zdrowym rozsądkiem, koniecznymi sądami ${ }^{19}$. Ma to związek z kluczową dla filozofii Szestowa antynomią rozumu

${ }^{15}$ Mikołaj Bierdiajew, Światopogląd Dostojewskiego, tłum. Henryk Paprocki (Kęty: Wydawnictwo Antyk - Marek Derewiecki, 2013), 28.

${ }^{16}$ Tamże, 44.

${ }^{17}$ Tamże, 45.

${ }^{18}$ Mikołaj Bierdiajew, Filozofia nierówności, tłum. Jacek Chmielewski (Kęty: Wydawnictwo Antyk - Marek Derewiecki, 2006), 40.

${ }^{19}$ Lew Szestow, Na szalach Hioba, tłum. Jacek Chmielewski (Warszawa Fundacja Aletheia, 2003), 55. 
i wiary, symbolizowanej przez Ateny sfery powszechnie uznawanych prawd, faktów, zależności z jednej strony, oraz z drugiej - symbolizowanej przez Jerozolimę sfery wiary, tego co absurdalne, niemożliwe, irracjonalne, sprzeczne z rozumem. Przeznaczeniem człowieka jest wyzwolenie się z tyranii rozumu, odrzucenie świata, który na nim się opiera, zanegowanie konieczności. W takim ujęciu, Iwan Karamazow byłby kimś, kto jednoznacznie opowiada się po stronie rozumu, a zatem odrzuca owo najistotniejsze dla człowieka doświadczenie, wybierając świat w którym indywidualna wolność człowieka zostaje stłumiona. Zupełnie inaczej traktuje Szestow postać Karamazowa w książce Dostojewski i Nietsche. Filozofia tragedii. Podobnie jak Bierdiajew, Szestow stawia tu Karamazowa obok Raskolnikowa, jednakże w tym wypadku są oni postaciami tragicznymi - to „marzyciele, romantycy, twórcy projektów przyszłego wspaniałego ustroju społecznego, oddani przyjaciele ludzkości”, którzy „wyrzekli się nagle swego marzycielstwa i wzniosłości i zrozumieli, że ich rozmowy o ideałach są czczą gadaniną, nie wnoszącą krzty prawdy do społecznej skarbnicy ludzkiej wiedzy"20, odrzucający świat, doktryny filozoficzne, Naturę, wzniosłe idee. Są oni samotnymi jednostkami ludzkimi, prowadzącymi walkę z tym, co ogólne, naukowe, etyczne, etc. ${ }^{21}$

Udziałem Karamazowa staje się zatem doświadczenie tragedii, w którym człowiek uświadamia sobie, że otaczająca go rzeczywistość pozostaje do cna zafałszowana i zmitologizowana, będąc domeną tego co ogólne - nauki, praw, logiki, konieczności. Jednym z elementów owej zafałszowanej rzeczywistości, jest filozofia uzurpująca sobie miano nauki i aspirująca do obiektywizmu, na którym ufundowane jest jej roszczenie do całościowego objaśnienia świata. Jak pisze Cezary Wodziński, rolą tak ujętej idealistycznie zorientowanej filozofii, jest zdaniem Szestowa eliminowanie z rzeczywistości wszystkiego, co „problematyczne” i przenoszenie w sferę rzeczy niepoznawalnych, a zatem nieistniejących, tego wszystkiego, co budzi niepokój, strach, niepewność ${ }^{2}$. Uświadomienie sobie charakteru otaczającej rzeczywistości stanowi treść owego kluczowego doświadczenia, które prowadzi do jednostkowego buntu i odrzucenia wszystkich „praw” i „oczywisto-

${ }^{20}$ Tenże, Dostojewski i Nietzsche. Filozofia tragedii, tłum. Cezary Wodziński (Warszawa: Wydawnictwo Czytelnik, 1987), 128.

${ }^{21}$ Tamże, 155-156.

${ }^{22}$ Cezary Wodziński, Wiedza a zbawienie (Gdańsk: Fundacja Terytoria Książki, 2017), 45. 
ści”. Przykładem takiego buntu był dla Szestowa przede wszystkim bohater Notatek z podziemia, wielokrotnie powracający w pismach rosyjskiego filozofa, ale śladów podobnej postaw doszukiwał się on także u Iwana Karamazowa.

4.

U obu filozofów mamy zatem dwie zasadniczo różniące się interpretacje postaci Iwana Karamazowa. Wedle Bierdiajewa, jest to nadużywający wolności nihilista, który w pogoni za doczesną szczęśliwością odrzuca Boski porządek, co w konsekwencji prowadzi go do opartej na przemocy tyranii, natomiast wedle Szestowa jest on buntownikiem nie przeciwko Bogu, lecz przeciwko światu, który rządzony jest przez bezosobowy Rozum kreujący prawa, zasady i uzasadniający konieczności. Obie te interpretacje mogą budzić pewne zastrzeżenia.

Dyskusyjna jest u Mikołaja Bierdiajewa próba oceny przyczyn buntu Karamazowa. Kwestia ta o fundamentalnym znaczeniu zostaje przez rosyjskiego filozofa potraktowania w gruncie rzeczy dość zdawkowo - wspomina on o „łzie dziecka”, uznając ją za element Boskiego porządku, a sprzeciw wobec niej za wyraz dążności do doczesnego szczęścia. Tymczasem Iwan w rozmowie ze swym bratem Aloszą, owszem, powołuje się na łzę dziecka jako przyczynę zwrócenia Bogu „biletu do zbawienia”, ale wcześniej opisuje chłopca rozszarpanego na rozkaz generała przez psy i dziewczynkę dręczoną przez swych opiekunów. Owe cierpienia to coś więcej niż „łza dziecka”, a uznanie ich za element Boskiego porządku świata lub nadawanie im jakiegokolwiek sensu albo chociażby przyjęcie, że mimo tych cierpień sens istnieje, tyle że nieosiągalny dla człowieka, budzi poważne wątpliwości. Odnieść można wrażenie, że Bierdiajew w gruncie rzeczy ogranicza się do stwierdzenia, że należy właśnie uczynić to przeciw czemu Karamazow protestuje - a mianowicie zaakceptować fakt cierpienia dziecka rozszarpywanego przez psy, a uczynić to należy w imię obietnicy zbawienia i wiary w Boski porządek. Istotne jest ponadto, że Bierdiajew w gruncie rzeczy nie odnosi się do motywów kierujących Karamazowem, a mówiąc ściślej - interpretuje je nader opacznie, wbrew bowiem tejże interpretacji Karamazow nie żąda powszechnej ziemskiej szczęśliwości, nie próbuje podważać Boskiego porządku jako takiego - natomiast odmawia uznania porządku, którego elementem jest zbrodnia popełniona na dziecku. 
Trudno nazwać taką postawę nihilistyczną, nie wynika ona z dogmatycznego odrzucenia wszelkich wartości, lecz raczej z niemożności uznania czegokolwiek, o ile takie uznanie miałoby wiązać się $\mathrm{z}$ akceptacją cudzego cierpienia.

Chybiony także wydaje się zarzut ateizmu, notabene sprzeczny z uznaniem Iwana Karamazowa za buntownika przeciw Bogu (nie sposób wszak odrzucać istnienie Boga i jednocześnie się przeciw niemu buntować). Iwan Karamazow nie ma wątpliwości co do istnienia Boga, co więcej fakt, iż On jest, a mimo to na świecie istnieje zło, stanowi fundament całego dylematu. Można uznać Karamazowa za bluźniercę, lecz nie za ateistę. Trafnie w tym kontekście zauważa Bohdan Urbankowski, że „ateizm jest w jakimś sensie wzięciem Boga w obronę, bluźnierstwo nie znosi kompromisów ${ }^{23}$ ". I wreszcie nie można zgodzić się z twierdzeniem Bierdiajewa, że Iwan buntuje się przeciw Bogu w imię jakkolwiek pojętej wolności. Otóż treścią tego buntu nie jest przecież żądanie, by Bóg zwrócił człowiekowi wolność; wręcz przeciwnie, Iwan zarzuca $\mathrm{Mu}$, że pozwala człowiekowi korzystać ze swej wolności w taki sposób, jak czyni to generał nakazujący rozszarpanie dziecka przez psy. Innymi słowy treścią zarzutu jest to, że Bóg lekkomyślnie pozostawił człowiekowi wolność, skutkującą złem. W przypowieści Iwana Wielki Inkwizytor zarzuca Chrystusowi, że ten obdarzył człowieka wolnością, bowiem zapragnął „dobrowolnej miłości człowieka, aby z wolnej woli poszedł za Tobą (Chrystusem - przyp. M.K.)”. Tymczasem ludzie odczuwają wolność jako „straszne brzemię” i ogłaszają w końcu że nie w Chrystusie jest prawda ${ }^{24}$.

Także interpretacja przyjęta przez Lwa Szestowa budzić może pewne wątpliwości, innej jednakże natury niż w wypadku Mikołaja Bierdiajewa.

Jak zauważa Cezary Wodziński, opis doświadczenia tragicznego w myśli Szestowa, zostaje uzupełniony przez nową perspektywę, wyjście z „sytuacji kryzysowej”, przekroczenie perspektywy dotychczasowej. Ów nowy wymiar ma charakter religijny ${ }^{25}$ i wyraża się w pojęciu wiary ujmowanej w swoisty sposób - jako zjawisko pokrewne szaleństwu, jako coś, co z punktu widzenia rozumu pozba-

${ }^{23}$ Bohdan Urbankowski, Dostojewski: dramat humanizmów (Warszawa: Wydawnictwo ALFA, 1994), 105.

${ }^{24}$ Fiodor Dostojewski, Bracia Karamazow, tłum. Aleksander Wat (London: Puls Publication Ltd., 1993), 288.

${ }^{25}$ Wodziński, Wiedza a zbawienie, 190. 
wione jest sensu. Wiara jest absurdalna, niemożliwa do zinterpretowania w kategoriach racjonalnych, wydarza się poza dobrem i złem, poza prawdą i fałszem ${ }^{26}$. Wiara taka, co istotne w aspekcie niniejszych rozważań, sama w sobie pozwala na otwarcie ścieżki wiodącej ku Stwórcy. Jest zatem przede wszystkim drogą do zbawienia. O ile poruszając się na gruncie myśli Szestowa, potraktować by postawę Iwana Karamazowa jako bunt przeciwko rozumowemu, naturalnemu porządkowi świata, to nie może podlegać wątpliwości, że w jego przypadku konsekwencją tegoż buntu nie będzie „skok wiary” - koncepcja zaczerpnięta przez Szestowa od Kierkegaarda - lecz właśnie odwrócenie się od Boga, odrzucenie jego oferty zbawienia, zwrócenie się ku doczesności w imię solidarności z cierpiącymi, a przede wszystkim odrzucenie tego, co było jednym z najistotniejszych elementów wiary w rozumieniu Szestowa - a mianowicie przekonania, że Bóg może sprawić, by niemożliwe stało się możliwym i by to, co się stało, nigdy się nie wydarzyło. Karamazow uznaje, że śmierć dziecka jest czymś, czego w żadnym wypadku nie da się pominąć, zanegować lub zrównoważyć przy pomocy jakiejkolwiek abstrakcji. Jest to nieodwracalny fakt, którego nie można pozostawić za sobą wybierając Boga. Z tych też powodów trudno byłoby przyjąć, że sprzeciw ten wynika z wymogów „euklidesowego rozumu” (wzmianka Karamazowa o „euklidesowym rozumie” jest zresztą wyraźnie ironiczna).

5.

Czy zatem możliwe jest w ogóle jednoznaczne ujęcie i ocena postaci Iwana Karamazowa? Czy możliwe jest sformułowanie odpowiedzi na zadane przezeń pytanie o to, czy człowiek ma prawo w imię zbawienia zgodzić się na cierpienie dziecka? Dorota Jewdokimow, widząc w Karamazowie postawę odrzucenia hierarchicznie nadrzędnej pozycji Boga i stanowionego przezeń prawa ${ }^{27}$, stwierdza że słowa Aloszy Karamazowa o Chrystusie cierpiącym i wybaczającym sprawiają, że dowód okrucieństwa Boga w postaci milczącego przyzwolenia na cierpienie dzieci traci swą $\operatorname{moc}^{28}$. Z powyższą interpretacją trudno się zgodzić - Iwan Karamazow,

26 Tamże, 245.

${ }^{27}$ Dorota Jewdokimow, Człowiek przemieniony. Fiodor M. Dostojewski wobec tradycji Kościoła Wschodniego (Poznań: Wydawnictwo Naukowe UAM, 2009), 161.

${ }^{28}$ Tamże, 206. 
jak już wskazano, nie buntuje się przeciwko „nadrzędnej pozycji Boga i stanowionemu przezeń prawu", tylko przeciwko Jego bezczynności wobec cierpienia, wynikającej z pozostawienia ludzi samym sobie. Zauważa to sama autorka, mówiąc o Jego „milczącym przyzwoleniu” na cierpienie. Po wtóre zauważyć należy, że na słowa Aloszy o których wspomina D. Jewdokimow, Iwan Karamazow reaguje przypowieścią o Wielkim Inkwizytorze, stanowiącą sedno jego oskarżenia Chrystusa o lekkomyślne podarowanie ludziom „przeklętego daru” wolności. W gruncie rzeczy można zaryzykować twierdzenie, że ubezwłasnowolnienie i zniewolenie zaprowadzone przez Wielkiego Inkwizytora to zdaniem Karamazowa odpowiedź na niesprawiedliwość i zło wynikłe z rezygnacji przez Chrystusa z zaprowadzenia Bożego porządku w doczesności. Karamazow domaga się odpowiedzi na zło, a Wielki Inkwizytor takiej odpowiedzi, jakkolwiek opartej na zniewoleniu i przemocy, udziela. Trudno zatem uznać, by racje Iwana Karamazowa „traciły moc”. Nawet jeśli Karamazow nie akceptował tego, co reprezentował Wielki Inkwizytor, to, jak się wydaje, uznawał że racje przez niego reprezentowane są próbą odpowiedzi na nieobecność Boga na świecie - Jego odejście niejako skazuje ludzkość na Wielkiego Inkwizytora. Wydaje się, że z tego punktu widzenia więcej racji ma Michał Kruszelnicki, który powołując się na głos badaczy Dostojewskiego stwierdza, że „pomimo wysiłku jaki Dostojewski włożył w opracowanie rozdziału o Zosimie, nie istnieje w ogóle możliwość udzielenia racjonalnej odpowiedzi na oskarżenie wniesione przez Iwana" ${ }^{29}$. Uzupełnieniem tego jest uwaga Bohdana Urbankowskiego: „Ostatnie miesiące życia pisarza to okres morderczej walki z bohaterem (Iwanem Karamazowem - M. K.), którego obdarzył zdolnością buntu. Nie mogąc go pokonać, Dostojewski zrobi zeń szaleńca, nawet tchórzliwego zbrodniarza. Zohydzi - ale jednak nie pokona"30.

Michaił Bachtin w cytowanym już dziele wspomina o myślicielach i krytykach, którzy dokonywali „zhomofonizowania” myśli filozoficznej Dostojewskiego, usiłując wtłoczyć wielorakość świadomości w homofoniczny system jednego światopoglądu. Jednym $z$ takich myślicieli był zdaniem Bachtina Szestow ${ }^{31}$. Z kolei cytowany przez Borysa Brusowa Sergiusz Bułhakow stwierdza, że „Dostojewski nie był filozofem - systematykiem, nie przeciwstawiał argumentów argu-

\footnotetext{
${ }^{29}$ Kruszelnicki, Dostojewski, tamże, 195

${ }^{30}$ Urbankowski, Dostojewski: dramat humanizmów, 237.

${ }^{31}$ Bachtin, Problemy poetyki Dostojewskiego, 15.
} 
mentom, obalając jedne za pomocą innych i dochodząc następnie do tego lub innego ostatecznego wniosku ${ }^{32}$ ". Wydaje się że opinie te są trafne, ale czy oznacza to konieczność odrzucenia, zanegowania rozważań Szestowa i Bierdiajewa? Frederick Copleston pisze w tym kontekście: „Dialektyka poglądów w powieściach Dostojewskiego stawia ludzi [...] nie przed teoretycznymi rozwiązaniami problemów, lecz przed możliwościami ich wyboru. Pisarz nie podejmuje się powiedzieć swoim czytelnikom, czy Bóg istnieje, czy nie istnieje, albo czy istoty ludzkie są swobodnie działającymi podmiotami, czy tylko produktami ich środowiska. Daje on czytelnikom do wyboru - opowiedzieć się za Bogiem lub przeciw Bogu, za wolnością lub przeciw wolności. Nie dostarcza dowodów że te tezy są prawdziwe, a tamte fałszywe, przedstawia przeciwstawne stanowiska, między którymi człowiek musi wybrać33". Dodać można, że nierozstrzygalne dylematy i problemy oraz konieczność udzielenia odpowiedzi na pytania, na które odpowiedzieć nie sposób, to zdaniem Dostojewskiego doświadczenie wspólne każdemu człowiekowi, o fundamentalnej wadze dla jego egzystencji. Jednocześnie ponawiane próby odpowiedzi na owe pytania, same w sobie, nawet gdy odpowiedzi tych sformułować nie sposób, stanowią nieodłączny składnik owej egzystencji, a ich podejmowanie to przeznaczenie człowieka i jego moralny obowiązek. W tym sensie filozoficzna refleksja nad takimi postaciami, jak Iwan Karamazow, posiada swą wartość nawet jeśli nie prowadzi - bo prowadzić nie może - do jednoznacznych, jasnych konkluzji i rozstrzygnięć. Z tych powodów brak jest podstaw do całkowitego i jednoznacznego zdezawuowania i odrzucenia rozważań Szestowa i Bierdiajewa, nawet przy wszystkich poczynionych zastrzeżeniach, nie sposób potraktować ich bowiem jako nadających się do jednoznacznej i jasnej falsyfikacji tez, które na drodze określonej argumentacji mogą zostać obalone. Oczywiście nie wyklucza to krytycznej oceny takich stanowisk - czego przykłady można znaleźć powyżej. Jednakże krytyka taka musi uwzględniać ów szczególny charakter zarówno samego pisarstwa Dostojewskiego, jak i wynikających z tego charakteru jego filozoficznych interpretacji, a podejmując ją należy mieć świadomość, że jej celem i efektem nie może być sformułowanie ostatecznego i nienaruszalnego stanowiska, lecz raczej próba zmierzenia się z egzystencjalnymi zagadnieniami, których nierozwiązywalność jest udziałem każdego z nas.

\footnotetext{
${ }^{32}$ Bursow, Osobowość Dostojewskiego, 193.

${ }^{33}$ Frederick Copleston, Historia filozofii, t. 10. Filozofia rosyjska, tłum. Bohdan Chwedeńczuk (Warszawa: Instytut Wydawniczy PAX, 2009), 135.
} 
6.

Czy opierając się zatem na przykładzie pisarstwa Dostojewskiego i charakterze podnoszonych przezeń problemów oraz filozoficznych dysput, jakie owe problemy wzbudziły, należy całkowicie odrzucić postulaty Stanisława Gałkowskiego? Po pierwsze, zwrócić należy uwagę na praktyczne konsekwencje realizacji tychże postulatów. Otóż bowiem, jeśli faktycznie uznamy, że pisarstwo te zawiera treści, których nie sposób uznać za zestawienie sądów oznajmujących, nadających się do intersubiektywnej, jednoznacznej weryfikacji i z racji tego nie można przyznać mu miana refleksji o charakterze filozoficznym, to jak potraktować dzieła Bierdiajewa i Szestowa, ale także Alberta Camus czy Karla Jaspersa - traktujące o tym pisarstwie? Podkreślić przy tym należy, że refleksje zawarte w owych dziełach nie mają charakteru rozważań z zakresu estetyki czy teorii powieści (a zatem powieści Dostojewskiego nie stanowią $\mathrm{w}$ nich niefilozoficznego przedmiotu filozoficznych rozważań, jak ma to miejsce w przypadku filozoficznych rozważań na temat dzieła sztuki), a problematyka utworów Dostojewskiego jest traktowana przez wymienionych filozofów jako bezpośredni punkt wyjścia, a zarazem materię rozważań na temat kondycji człowieka, jego stosunku do Boga, przyczyn zła - to jest kwestii które powszechnie przyjmowane są jako przedmiot dociekań filozoficznych.

Wydaje się, że teza Stanisława Gałkowskiego nie jest błędna w samej swej istocie - słusznie bowiem zwraca on uwagę na zagrożenie, jakie potencjalnie może wynikać ze zbytniego nasycenia tekstu filozoficznego takimi elementami literackimi jak metafora, co utrudnia czy też wręcz uniemożliwia krytyczną analizę tekstu filozoficznego, a w skrajnych przypadkach może prowadzić do sytuacji, gdy autor takiego tekstu, wykorzystując jego niejednoznaczność, uchyla się od odpowiedzi na krytykę, zarzucając adwersarzowi niezrozumienie teksu. Istotnie w tak opisywanej sytuacji ów krytyk nie dysponuje możliwościami odpowiedzi, a próba jej sformułowania mimo wszystko może doprowadzić do tego, że dyskusja wobec niejednoznaczności swego przedmiotu może zamienić się w „konkurs poetycki”34. Uwzględniając to, trzeba jednak stwierdzić, że wątpliwości budzi teza wywiedziona z powyższych stwierdzeń dotyczących języka, jakim operuje filozofia i literatura o konieczności trwałego ich rozdzielenia, bez pozostawiania jakichkolwiek

\footnotetext{
${ }^{34}$ Gałkowski, „Granica filozofii”, 49.
} 
obszarów wspólnych lub chociażby sąsiadujących i oddziałujących na siebie. Uzasadniając tę tezę, S. Gałkowski stwierdza, że nie zachowanie owej granicy musi prowadzić do wchłonięcia filozofii przez literaturę, czy też ściślej mówiąc - przekształcenia filozofii w literaturę. Jeżeli filozofia i literatura mówią „to samo i tak samo", a literatura jest przecież piękniejsza, to po co nam filozofia?, pyta w zakończeniu swego artykułu autor ${ }^{35}$. Takie stanowisko zakłada, jak się zdaje, redukcję zarówno literatury, jak i filozofii do swego rodzaju monolitów, dziedzin wewnętrznie jednolitych i pozbawionych jakiegokolwiek zróżnicowania. Tymczasem jest to, jak się zdaje, uproszony obraz. Trudno bowiem nie dostrzec, że to, co zwykle określane jest mianem filozofii, obejmuje przecież badania obejmujące zagadnienia i kwestie zróżnicowane i nieraz od siebie odlegle, co ma wpływ i na język opisu i na metody badawcze.

Ma to istotne znaczenie dla kwestii potencjalnego zagrożenia zastąpienia filozofii przez literaturę - o ile bowiem można wyobrazić sobie, że problemy etyczne, egzystencjalne lub metafizyczne, takie jak Bóg, istnienie zła, przypadek i konieczność itp. mogą być przedmiotem zarówno rozważań filozoficznych, jak i utworu literackiego, co potencjalnie mogłoby prowadzić do zlania się w tym zakresie literatury i filozofii w jedno, to trudno sobie wyobrazić dzieło literackie, którego treścią byłyby rozważania z zakresu logiki czy filozofii nauki lub polityki. Wydaje się bowiem, iż refleksja filozoficzna dotycząca takich i podobnych kwestii, jest na tyle swoista w zakresie formy językowej i treści, że gwarantuje to zachowanie całkowitej autonomii od literatury. Innymi słowy - spośród wielu obszarów jakimi zajmuje się filozofia, istnieją takie które ze swej natury mogą stanowić także treść dzieła literackiego - lecz nie dotyczy to całej filozofii jako takiej. Co więcej - literatura z racji swych cech, może w bardziej przenikliwy sposób opisywać owe zagadnienia, stanowiąc $w$ ten sposób nie tylko źródło inspiracji dla filozofii, ale wręcz bezpośrednich treści filozoficznych, inicjujących dyskusje i dalsze badania tychże zagadnień, już na gruncie „czystej” filozofii. Jednym z takich zagadnień jest na przykład metafizyka, ujmowana jako refleksja nad bytem i istnieniem. Władysław Stróżewski zwraca w tym kontekście uwagę na następujący fakt: „Istnienie jest czymś najbardziej immanentnym, najbardziej »własnym« [...], a przeżycie własnej egzystencji najbardziej wewnętrznym ze wszystkich doświadczeń, jakie stać się mogą doświadczeniem człowieka.

\footnotetext{
35 Tamże, 51.
} 
Równocześnie jest to doświadczenie najtrudniejsze do adekwatnego opisania. [...] Istnienie zdaje się wymykać wszystkim naszym kategoriom pojęciowym, przekraczać je, pozostawać samo w sobie w sferze niewyrażalnego. Poezja jest tu - być może - w lepszej sytuacji: uwolniona od rygorów racjonalnego dyskursu zdolna jest niekiedy mówić o istnieniu wprost, odwołując się do konkretu i intymnego przeżycia" ${ }^{36}$. Z kolei Roman Ingarden wskazuje, że jednym z doświadczeń człowieka, jest niemożliwa do wygaszenia tęsknota za kontemplacyjnym zatopieniem się w jakościach metafizycznych, stanowiąca z jednej strony ostateczne źródło poznania filozoficznego, z drugiej zaś - źródło twórczości artystycznej i rozkoszowania się sztuką ${ }^{37}$. Wydaje się zatem, że w pewnych swych aspektach, z racji tak opisanego powinowactwa, filozofia i literatura są niejako skazane na siebie, a ich „współpraca” jak również przenikanie problematyki z obszarów literatury do filozofii, może w konsekwencji doprowadzić do wzbogacenia tej ostatniej poprzez uchwycenie treści niedostępnych dla czystego dyskursu naukowego.

George Steiner, który związkom filozofii i literatury poświęcił swój esej Poezja myślenia, zwraca w nim uwagę na wspólny dla obu tych dziedzin językowy charakter - jego zdaniem „zajmują one tę samą generatywną choć skrajnie ograniczoną przestrzeń"38. Konsekwencją tego są związki filozofii i literatury wyrażające się tworzeniem tekstów filozoficznych „via literackie narzędzia i mody”, „interakcje i rywalizacje poetów, powieściopisarzy, scenarzystów z jednej strony, a zadeklarowanych myślicieli z drugiej”39. O ile "poezja zmierza do ponownego wynalezienia języka [...], a filozofia pracuje nad uczynieniem języka rygorystycznie przejrzystym”, to w ostatecznym rozrachunku „całościową macierzą (obu zjawisk - M.K.) pozostaje ludzki dyskurs"40. Ów wspólny rdzeń filozofii i literatury determinował ich związki i relacje, które miały miejsce na przestrzeni całej historii obu dziedzin od starożytności począwszy do chwili obecnej, przesądza też o tym, że owe związku nadal będą zachodzić. $Z$ tego powodu próba hermetycznego rozdzielenia obu dziedzin jest, jak się zdaje, skazana na niepowodzenie. $Z$ drugiej jed-

${ }^{36}$ Władysław Stróżewski, Wokół piękna. Szkice z estetyki (Kraków: Towarzystwo Autorów i Wydawców Prac Naukowych Uniwersitas, 2002), 120.

${ }^{37}$ Roman Ingarden, O dziele literackim (Warszawa: PWN, 1988), 370-371.

${ }^{38}$ George Steiner, Poezja myślenia, tłum. Bogdan Baran (Warszawa: Wydawnictwo Aletheia, 2016), 10.

${ }^{39}$ Tamże, 11.

${ }^{40}$ Tamże, 242. 
nak strony, swoistość literatury i filozofii dotychczas podtrzymywała ich wzajemną autonomię i odrębność; nic nie zapowiada, by ten stan rzecz mógł ulec jakiejś znaczącej zmianie w przyszłości.

\section{Bibliografia}

Bachtin Michaił. Problemy poetyki Dostojewskiego. Tłum. Natalia Modzelewska. Warszawa: Państwowy Instytut Wydawniczy, 1970.

Bierdiajew Mikołaj. Filozofia nierówności. Tłum. Jacek Chmielewski. Kęty: Wydawnictwo Antyk - Marek Derewiecki, 2006.

Bierdiajew Mikołaj. Światopogląd Dostojewskiego. Tłum. Henryk Paprocki. Kęty: Wydawnictwo Antyk - Marek Derewiecki, 2013.

Bursow Borys. Osobowość Dostojewskiego. Tłum. Alicja Wołodźko. Warszawa: Państwowy Instytut Wydawniczy, 1983.

Copleston Frederick. Historia filozofii, t. 10. Filozofia rosyjska. Tłum. Bohdan Chwedeńczuk. Warszawa: Instytut Wydawniczy PAX, 2009.

Dostojewski Fiodor. Bracia Karamazow. Tłum. Aleksander Wat. London: Puls Publication Ltd., 1993.

Gałkowski, Stanisław. „Granica filozofii. Metafora w filozofii na przykładzie języka Józefa Tischnera". W: Filozofia w literaturze, literatura w filozofii, red. Agnieszka Iskra-Paczkowska, Stanisław Gałkowski i Marek Stanisz, 42-51. Rzeszów: Wydawnictwo Uniwersytetu Rzeszowskiego, 2013.

Grossman, Leonid. Dostojewski. Tłum. Seweryn Pollak. Warszawa: Czytelnik, 1968.

Ingarden, Roman. O dziele literackim. Warszawa: PWN, 1988.

Jewdokimow, Dorota. Człowiek przemieniony. Fiodor M. Dostojewski wobec tradycji Kościoła Wschodniego. Poznań: Wydawnictwo Naukowe UAM, 2009.

Kruszelnicki, Michał. Dostojewski. Konflikt i niespełnienie. Warszawa: Wydawnictwo Naukowe Scholar, 2017.

Przybylski, Ryszard. Dostojewski i „przeklęte problemy”. Warszawa: Wydawnictwo Sic!, 2010.

Steiner, George. Poezja myślenia. Tłum. Bogdan Baran. Warszawa: Wydawnictwo Aletheia, 2016.

Stirner, Max. Jedyny i jego własność. Tłum. Joanna i Adam Gajlewiczowie. Warszawa: Wydawnictwo Naukowe PWN, 1995.

Stróżewski, Władysław. Wokół piękna. Szkice z estetyki. Kraków: Towarzystwo Autorów i Wydawców Prac Naukowych Universitas, 2002.

Szestow, Lew. Dostojewski i Nietzsche. Filozofia tragedii. Tłum. Cezary Wodziński. Warszawa: Wydawnictwo Czytelnik, 1987.

Szestow, Lew. Na szalach Hioba. Tłum. Jacek Chmielewski. Warszawa: Fundacja Aletheia, 2003. 
Urbankowski, Bohdan. Dostojewski: dramat humanizmów. Warszawa: Wydawnictwo ALFA, 1994.

Wodziński, Cezary. Trans, Dostojewski, Rosja. Gdańsk: Fundacja Terytoria Książki, 2018.

Wodziński Cezary. Wiedza a zbawienie (Gdańsk: Fundacja Terytoria Książki, 2017).

\section{Summary}

\section{Relationships between literature and philosophy: the case of Ivan Karamazov}

The author argues in favour of defining a clear distinction between literature and philosophy in view of their outright different nature. Intersubjectivity in communication and verifiability of theses are typical in philosophy. He quotes as example the case of Ivan Karamazov and his existential dilemmas which inspired Lev Shestov's and Nicolai Berdyaev's philosophical thoughts in order to observe that philosophy covers versatile domains of study such as logic, which is not tied up with literature directly, as well as fields such as philosophy of existence or metaphysics which have been drawing all along from literary output indirectly as a source of inspiration and directly providing strictly philosophical substance for polemics and studies. None of that jeopardizes the independence of philosophy from literature.

Keywords: literature, philosophy, delimitation, ambiguity, Dostoyevsky, Shestov, Berdyaev

\section{Zusammenfassung}

\section{Über die Beziehungen zwischen Literatur und Philosophie} am Beispiel der Figur von Iwan Karamazow

Stanislaw Gałkowski weist im Artikel Die Grenze der Philosophie. Die Metapher in der Philosophie am Beispiel der Sprache von Józef Tischner auf die Notwendigkeit hin, zwischen Literatur und Philosophie zu unterscheiden. Die Philosophie sei demnach ein Gebiet, dessen Anforderungen die intersubjektive Kommunizierbarkeit und Überprüfbarkeit von verfochtenen Thesen sind. Indem ich mich auf das Beispiel der Figur von Iwan Karamazow und auf seine existentiellen Dilemmas stütze, die den Nährboden für philosophische Überlegungen von Leo Schestow und Nikolai Berdiajew bildeten, weise ich nach, dass die Philosophie sowohl solche Forschungsbereiche, die keine Nahtstellen mit der Literatur haben (wie Logik) als auch solche, die das literarische Schaffen benutzten und immer noch benutzen (wie Existenzphilosophie o- 
der Metaphysik). Für jene Bereiche sind literarische Werke sowohl mittelbar eine Inspirationsquelle als auch unmittelbar philosophische Texte sensu stricte, indem sie die Grundlage für Polemik und weitere Forschungen bilden, was keinen Abbruch der Autonomie der Philosophie gegenüber der Literatur tut.

Schlüsselworte: literatur, Philosophie, Unterscheidung, Ambivalenz, Dostojewskij, Schestow, Berdiajew

Information about Author:

MARCIN KOCHANOWSKI, PhD student at the Institute of Philosophy, Sociology and Journalism at the Faculty of Social Sciences of the University of Gdańsk; address for correspondence: University of Gdańsk, Faculty of Social Sciences, Institute of Philosophy, Sociology and Journalism, ul. Bażyńskiego 4, PL 80-309 Gdańsk; e-mail: piglet14@wp.pl 